\title{
THE DECLARATORY JUDGMENT AS AN EXCLUSIVE OR ALTERNATIVE REMEDY
}

\section{Edwin M. Borchard*}

$\mathrm{TN}^{\mathrm{N}}$ a recent Michigan case ${ }^{1}$ the seller of a boiler, claiming a chattel 1 mortgage therein for the unpaid purchase price, brought an action against the person who had bought the boiler at a bankruptcy sale of the property of the original buyer for a declaration that the plaintiff had the right to possession, or in the alternative, that the defendant was under a duty to pay the balance of the original purchase price. The defendant claimed to be the owner free of the mortgage. A majority of the Michigan Supreme Court, on its own motion, for the propriety of the proceeding was not questioned by the parties, dismissed without prejudice a judgment of the lower court in the plaintiff's favor on the ground that "the proper action is replevin. The proceeding for declaratory judgment is not a substitute nor alternative for the common law actions."

In so holding, the court has disregarded the terms of the Michigan Declaratory Judgment Act and an overwhelming practice in England and the United States. The dissenting opinion of Judge Potter is as sound as the dissenting opinion of Judge Sharpe in the Anway case of $1919^{2}$. on the issue of the constitutionality of declaratory judgments, a decision which the Michigan court, to their great credit, overruled in 1930. ${ }^{3}$ It may be hoped that it will not take so many years to overrule the present decision.

Before adducing the terms of the statute and the practice, it may be observed that by the action for a declaration of his right to possession the plaintiff was placing in issue the only vital point in controversy, namely, whether his chattel mortgage was valid or not. A decision on that point was decisive of the case, as he evidently did not want the boiler. The court, though competent to decide the case by declaration,

* Professor of Law, Yale University. Ph.D., Columbia; LL.B., New York Law School, Columbia Law School; LL.D. (hon.) Berlin University. Author - Diplomatic Protection of Citizens Abroad, The Declaratory Judgment, etc.-Ed.

1 Miller v. Siden, 259 Mich. I9, 242 N. W. 823 (1932).

2 Anway v. Grand Rapids Ry. Co., 2 II Mich. 592, I79 N. W. 350 (I920).

${ }^{8}$ Washington-Detroit Theatre Co. v. Moore, 249 Mich. 673, 229 N. W. 618, 68 A. L. R. I05 (1930). This was facilitated by the enactment in 1929 of a new and more explicit statute. 
a simple form perfectly adapted to the purpose, forced the plaintiff to commence all over again, and to adopt a form of proceeding expensive and cumbersome, in order to achieve the identical goal originally sought. This seems improper as a matter of law and unwise as a matter of judicial policy.

As a matter of law, the statute of Michigan ${ }^{4}$ and the parallel statutes in the United States and elsewhere make it abundantly clear that the action for a declaratory judgment is not, and was never intended to be, an exclusive or extraordinary remedy, available only on evidence that no existing remedy sufficed. On the contrary, in accordance with the express terms of the statute and in accordance with an almost uniform practice of decades, it is the simplicity of declaratory relief which has commended it as a remedy to be employed whenever an uncomplicated issue is presented and when the determination of that issue would settle the controversy. This form of relief was ideally suited to the purpose of the Miller case. ${ }^{5}$

Let us examine the Michigan statute. Section I states that "no action or proceeding in any court of record shall be open to objection on the ground that a merely declaratory judgment, decree or order is sought thereby." (Italics mine.) That is to say, even though an action for replevin or for damages or what not might have been possible, the action is not to be open to objection because it was brought for a declaration of rights. The words quoted were designed to prevent exactly what the Michigan court has just done. The section goes on to say, "And the court may, in cases of actual controversy, make binding declarations of rights whether any consequential relief is or could be claimed, or not." (Italics mine.) That is, although the plaintiff "could" have sought more coercive relief in the form of specific performance, replevin, damages, etc., the fact that he chose to confine

* Mich. Pub. Acts 1929, No. 36, p. 68, Mich. Comp. Laws 1929, secs. 13903-9.

5 See Royal Bank of Canada v. Coughlan, 28 Br. Col. Rep. 247 (1920) (where a practically identical issue was determined by declaration); Greene v. Riordan, $97 \mathrm{Cal}$. App. 462, 276 Pac. 14I (1929) (plaintiff claims declaration that his written instrument was a mortgage and not a deed); Brownell v. Board of Education of Saratoga Springs, 239 N. Y. 369,146 N. E. 630 (1925) (plaintiff, vendee of a building burned before delivery, claims lien on insurance money paid to vendor); Albutt v. Continental Guaranty Corp. of Canada, 4r Br. Col. 537 (1929); National Discount Corp. v. French, 2 D. L. R. 256 (Ont. 1928) (chattel mortgagee v. purchaser at sale). Graham v. Hamill, 35 Manit. Rep. 510 (I926) (plaintiff claims an equitable mortgage on defendant's home); Wallace v. Fogarty, [1926] Ir. R. 255 (I925) (that a certain mortgage on defendant's land was valid); Smith v. Cunningham, 34 N.Z. 385 (1915) (validity of plaintiff's as against defendant's mortgage on X's land). 
his demanded relief to a declaration of his rights is not to bar his action.

Like the rest of the section, these clauses find their source in English legal history. In the Chancery Procedure Act, 1852, the courts were given power to make declarations of right "without granting consequential relief." This was interpreted by the Court of Chancery to mean that a declaration could be made only in a case where the plaintiff, though having a right to consequential relief, chose not to ask for it. ${ }^{8}$ Even this narrow construction the Michigan court repudiates. But to indicate that the English people considered the construction unnecessarily narrow, the English Supreme Court Rules of 1883 , OrderXXV, Rule 5, from which the Michigan Act was taken, provide that the Supreme Court shall have power to make binding declarations of right "whether any consequential relief is or could be claimed or not." " That is, whether the parties could or could not have sought coercive relief is immaterial to the propriety of a declaration. No English court has ever suggested that the mere possibility of obtaining a coercive remedy is in principle a bar to an action for a declaration.

Section 2 of the Michigan Act provides that "declarations of rights and determinations of questions of construction, as herein provided for, may be obtained by means of ordinary proceedings at law or in equity, or by means of a petition on either the law or equity side of the court as the nature of the case may require." There is nothing here to indicate that the legislature considered the action for a declaration an extraordinary proceeding, to be disallowed in cases where the facts might have sustained a more drastic form of relief. On the contrary, the declaration is distinctly contemplated as an alternative remedy, the choice of which, as against other remedies, is left to the plaintiff, and the declaration will be issued provided on the merits he is entitled to the relief demanded and provided that the court concludes that the determination will settle the controversy. ${ }^{8}$

This is made even clearer by the concluding words of section 2,

${ }^{6}$ Rooke v. Lord Kensington, 2 K. \& J. (Ch.) 753, 69 Eng. Repr. 986 (I856).

7 Italics supplied. The New York Civil Practice Act, sec. 473 (1920) confers power on the supreme court "in any action or proceeding to declare rights and other legal relations ... whether or not further relief is or could be claimed." (Italics supplied.)

${ }^{8}$ Sec. 6 of the Uniform Declaratory Judgments Act provides: "The court may refuse to render or enter a declaratory judgment or decree where such judgment or decree, if rendered or entered, would not terminate the uncertainty or controversy giving rise to the proceeding." 
reading, "and where a declaration of rights is the only relief asked, the case may be noticed for early hearing as in the case of a motion." This indicates that the draftsman of the statute was aware of the fact that coercive relief as well as declaratory relief might be asked, alone or in combination. But when the plaintiff chooses to confine his demand to declaratory relief only, he has the advantage of an early hearing. This is an inducement to the submission of cases by actions for a declaration. As opposed to replevin, it determines the issue of title without the necessity for a bond, attachment, sheriff's fees, warehousing, and insurance, not to speak of other inconveniences and procedural pitfalls.

Section 3 of the Michigan Act provides:

"Where further relief based upon a declaration of rights shall become necessary or proper after such declaration has been made, application may be made by motion to any court having jurisdiction to grant such relief, for an order directed to any party or parties whose rights have been determined by such declaration to show cause why such further relief should not be granted forthwith, upon such reasonable notice as shall be prescribed by the court in the said order."

This would make it clear that a declaration may be sought and granted, even though further coercive relief might be or might have been possible. It assumes that declarations of rights alone might be and would be sought. It was assumed, on the basis of long experience, that, when a declaration of rights had settled the legal issue between the parties - in this case the question of title and the validity of the chattel mortgage - it would hardly be necessary for the sheriff to be invoked to enforce the judgment by coercion. It rarely has proved necessary. But if a losing party should have the temerity and recklessness to defy the court's declaratory judgment, which irrevocably fixes the rights of the parties, the winning party and the court are not helpless, but on motion, in which the declaratory judgment is res judicata, an order may issue carrying the judgment into coercive execution. The very terms of the section indicate that the declaration may and is usually expected to stand alone.

If further evidence of the error of the Michigan court were needed, it would be afforded by the fact that it is not uncommon practice to combine in one action the request for a declaration and for some coer-

${ }^{2}$ Cf. McFadden v. Lick Pier Co., 101 Cal. App. 12, 281 Pac. 429 (1929); Bentz v. Barclay, 294 Pa. 300, I 44 Atl. 280 (1928); 45 HARv. L. REv. 830 (1932). 
cive relief, ${ }^{10}$ or to pray for declaratory relief in the alternative. ${ }^{11}$ If there were any inconsistency between the two forms of relief, or if one excluded the other, as the Michigan court seems to assume, they could hardly be applied for in one and the same prayer for relief. The advantage of the combined request is that, while the coercive relief, such as injunction, may be denied, the declaration of rights may be granted - and the declaration of rights is the vital element in the plaintiff's relief. ${ }^{12}$

It will be observed, moreover, that section 7 of the Michigan Act provides that the "act is declared to be remedial, and is to be liberally construed and liberally administered with a view of making the courts more serviceable to the people." This section does not seem to have impressed the Michigan court, though the dissenting judge refers to it.

A few American decisions can be found in which the courts, in a particular case, have held that the possibility of a coercive remedy barred declaratory relief. This was because in those particular cases the courts believed in their discretion that the declaratory relief would not settle the issue or was, for some other substantial reason, inappropriate. ${ }^{13}$ But neither American nor English courts have adopted the

${ }^{10}$ Green v. Riordan, 97 Cal. App. 462, 276 Pac. 14I (1929) (declaration and money judgment sought - relief confined to determination of the nature of the written instrument and quieting of title); Brownell v. Board of Education of Saratoga Springs, 239 N. Y. 369, I 46 N. E. 630 (1925), rev'g 21 I App. Div. 823, 206 N. Y. S. 887 (1924) (specific performance and conveyance of title refused - declaration of legal relations granted); Butterick Pub. Co. v. Fulton \& Elm Leasing Co., I32 Mis. 366,229 N. Y. S. 86 (1928) (claim for damages refused and declaration of right to sab-let given); Beury v. Shelton, 15 I Va. 28, I44 S. E. 629 (1928) (proceeding begun under attachment statute but continued under declaratory judgment provision); London Ass'n of Shipowners v. London \& India Docks, L. R. [1892] 3 Ch. Div. 242; Attorney General v. Merthyr Tydfil Union, L. R. [1900] I Ch. Div. 516; Islington Vestry v. Hornsey U. C., L. R. [1900] I Ch. Div. 695; Grainger v. Order of Canadian Home Circles, 31 Ont. L. Rep. 461 (1914).

American courts have held that the parties must plead facts necessary to entitle them to further relief. City of San Diego v. Cuyamaca Water Co., 209 Cal. 105 at 15 I, 287 Pac, 475 at 496 (1930); Village of Grosse Pointe Shores v. Ayres, 254 Mich. 58, 235 N. W. 829 (193I); Bartlett v. Lily' Dale Assembly, 139 Mis. 338 at 339, 249 N. Y. S. 482 at 483 (193I).

${ }^{11}$ See Fess Oil Burners, Ltd. v. Mutual Investments, Ltd., [1932] 2 D. L. R. 16, an action to recover damages for conversion and wrongful detention of an oil burner or in the alternative a declaration that plaintiff was entitled to remove it.

${ }^{12}$ See cases supra, note 10.

${ }^{13}$ See Village of Grosse Pointe Shores v. Ayres, 254 Mich. 58, 235 N. W. 829 (193I); Loesch v. Manhattan Life Ins. Co. of New York, I28 Mis. 232, 218 N. Y. S. 412 (1926), 36 YALE L. J. 403 (1927); City of Williamsport v. Williamsport Water Co., 300 Pa. 439, 150 Atl. 652 (1930); 40 YALE L. J. 129 (1930), and a few 
unsustainable position that, as a matter of principle, parties must seek coercive relief whenever possible and may be denied declaratory relief in cases where they might have sought coercive relief. That would run counter to a uniform practice, and misinterpret the statutes.

Addressing itself to this very point, the Supreme Court of Virginia, in a recent case, remarked $:^{14}$

"The test of the applicability of the statute is the determination of the existence of an actual controversy. The manifest intention of the legislature, as expressed in sections 6r40a-6I40h of the Code, was to provide for a speedy determination of actual controversies between citizens, and to prune, as far as is consonant with right and justice, the dead wood attached to the common-law rule of 'injury before action' and a multitude of suits to establish a single right.

"The fact that a plaintiff or complainant might, by the insti-

other Pennsylvania cases cited ibid. 130. In these states and in others, declaratory judgments have been rendered in numerous cases where coercive judgments might have been sought.

14 Chick v. MacBain, I 57 Va. 60 at 66, 160 S. E. 214 at 216 (193I). In Tolle v. Struve, (Cal. App. 1932) 12 Pac. (2d) 61 at 62, the court answers the views of the Michigan court in Miller v. Siden as follows:

"Appellant asserts further that, if her attempt to terminate her obligations under the leases constituted a breach of legal duty, it was one which gave rise to a cause of action for remedial relief against her, and, that being so, there was no longer any room or occasion for the invocation of the statute authorizing declaratory relief. The statute itself seems to afford a complete answer, providing as it does (Code Civ. Proc., sec. 1060): 'He [the plaintiff] may ask for a declaration of rights or duties, either alone or eoith other relief. ...' (Italics ours.) We can conceive of no meaning to be attributed to the italicized language unless the statute contemplates the giving of declaratory relief as well after a breach of legal duty as before. This conclusion is strengthened by the additional language of the section that 'the court may make a binding declaration of such rights or duties, whether or not further relief is or could be claimed at the time.' The concluding sentence of the section further bears this out: 'Such declaration may be had before there has been any breach of the obligation in respect to which said declaration is sought.' (Italics ours.) The use of the word 'may' is permissive, not mandatory. It serves to make clear what the legislature feared might otherwise be obscure, in view of the fact that historically nearly all relief by way of judgment in commonlaw courts had been limited to redress for completed wrongs, that this statute contemplated declaratory relief, regardless of whether there had been an actual breach of obligation or not. It does not limit the right to such relief to cases where no breach has in fact occurred."

Cf. Oldham v. Moodie, 94 Cal. App. 88, 270 Pac. 688 (I928); Sheldon v. Powell, 99 Fla. 782 , 128 So. 258 (1930); Zoercher v. Agler, 202 Ind. 214, 172 N. E. 186 (1930); National City Bank of New York v. Waggoner, 230 App. Div. 88, 243 N. Y. S. 299 (I930). 
tution of an action or suit or series of actions or suits, eventually, through protracted and continuous litigation, have determined the same questions that may be determined once and for all in a declaratory judgment proceeding, has never, so far as we find, been held by the courts to deprive the courts of jurisdiction to enter a declaratory judgment wherein the entire rights of the parties can be determined and settled once and for all. Sections 6r40a-6r4oh of the Code above were enacted for that evident purpose, and section 6r40h expressly declares that the act is to be liberally interpreted and administered 'with a view to making the courts more serviceable to the people." "'

It is true that the English courts have adopted a rule that, where a specific statutory remedy has been provided for a given type of complaint or demand, the parties should resort to that specific remedy. ${ }^{18}$ Such a rule is unexceptionable. It is also true that an action for a declaration must be brought in a court having jurisdiction. And as a matter of fact a declaratory judgment may lie in certain cases, mainly those involving peril and insecurity, where no other form of action would have been possible. ${ }^{16}$ But in a case where several prayers for relief are possible, the court should not insist that a plaintiff adopt his most drastic and expensive remedy when a simple, mild, and inexpensive remedy will determine the issue and preserve his rights. The mere fact that a common-law action of the standard type might have been brought is no ground at all for denying a. declaration. A consistent practice of fifty years has established this conclusion beyond the possibility of doubt. The hope may be expressed that the Michigan court will take an early occasion to reconsider its position in the Miller case.

${ }^{15}$ Barraclough v. Brown, L. R. [1897] A. C. 615 at 623; Bull v. Attorney General of New South Wales, L. R. [1916] 2 A. C. 564; Grand Junction Waterworks Co. v. Hampton U. D. C., L. R. [1898] 2 Ch. Div. 331; Flint v. Attorney General, L. R. [1918] I Ch. Div. 216 (1917).

${ }^{18}$ See cases discussed in my article "Judicial Relief for Peril and Insecurity," 45 HaRv. L. REv. 793 (1932). 